\title{
Acquired Inhibitors to Coagulation Factors in a Male Patient with Systemic Lupus Erythematosus: A Case Report and Review of the Literature
}

\author{
Ozgur ERDEM, Orhan AYYILDIZ, Mehmet AYBAK \\ ${ }^{1}$ Dicle University Faculty of Medicine, Department of Family Medicine \\ ${ }^{2}$ Dicle University Faculty of Medicine, Department of Internal Medicine and Hematology \\ ${ }^{3}$ Dicle University Faculty of Medicine, Department of Physiology, Diyarbakir, TURKEY
}

\begin{abstract}
Acquired coagulation inhibitors are rare but acquired bleeding diathesis caused by autoimmune depletion or dysfunction of coagulation factors can be life-threatening. This occurs most frequently in elderly patients who lack disease associations. Acquired coagulation inhibitors may also arise in association with systemic lupus erythematosus (SLE). The groups of patients who suffer from SLE most frequently are women in their 2nd to 4th decade. In this case, we present a 22-year-old man with systemic lupus erythematosus who developed an acquired inhibitory to factor II, VIII, IX, X and von Willebrand factor (VWF).
\end{abstract}

Keywords: Acquired Coagulation inhibitors, Systemic Lupus Erythematosus

ÖZET

Sistemik Lupus Eritematozuslu Erkek Bir Hastada Akkiz Koagulasyon Faktör İnhibitör Gelişimi

Akkiz koagülasyon faktör inhibitörleri nadirdir ancak koagulasyon faktörlerinin disfonksiyonu veya otoümmün baskllanma nedenli akkiz kanama diyatezi yaşamı tehdit edebilir. Bu hastalıkla ilişkisiz olarak daha sık yaşı hastalarda ortaya çıkar. Akkiz koagulasyon inhibitörleri aynı zamanda Sistemik Lupus Eritematozus (SLE) ile ilişkili olarak da meydana gelebilir. SLE, 2. ile 4. dekat arasındaki kadınlarda sıktır. Bu olguda faktör II, VIII, IX, X ve von Willebrand faktör'e (vWF) karşı akkiz inhibitör gelişen 22 yaşında SLE'li bir erkek hasta sunulacaktır.

Anahtar Kelimeler: Akkiz koagulasyon inhibitörleri, Sistemik Lupus Eritematozus

\section{INTRODUCTION}

Systemic lupus erythematosus (SLE) is a chronic autoimmune disease, characterised by multisystemic involvement, with a broad spectrum of clinical and laboratory manifestations. ${ }^{1}$ Evidence from a broad range of basic science studies indicates that the pathogenesis of this disease is equally complex and may vary from patient to patient. The diverse expression of the common lupus syndrome may result from variable abnormalities in intersecting genetic, immunologic, hormonal, and environmental pathways. $^{2}$ 
The group of patients who suffer from SLE most frequently are women in their 2nd to 4th decade.,3 Coagulation dysfunctions in the course of SLE usually consist of thrombotic complications caused by the presence of antiphospholipid antibodies. Hemorrhagic events based on the production of antibodies directed against the coagulation factors are rarely observed in SLE. ${ }^{5}$

Acquired haemophilia is a rare but acquired bleeding diathesis caused by autoimmune depletion of factor VIII can be life-threatening. This occurs most frequently in elderly patients who lack disease associations. Acquired haemophilia may also seen with SLE, rheumatoid arthritis, Sjögren's syndrome, other autoimmune conditions, lymphoproliferative malignancy, pregnancy and as a drug reaction. ${ }^{6,7}$ Acquired inhibitors to other caogulations factors are very rare.

Here, we describe a male patient with clinically quiescent SLE who developed acquired inhibitors to coagulation factor II, VIII, IX, X and von Willebrand factor (vWF). We also review the literature on acquired coagulation inhibitors associated with SLE.

\section{CASE REPORT}

A 22-year-old man, with 3 years history of SLE was admitted to Dicle university hospital due to epistaxis and spontaneous ecchymoses in the elbow, knee and ankle. In addition, in the clinical history there was occasional petechia and subcutaneous ecchymoses on the trunk. On admission he didn't take treatment and SLE had been successfully controlled. No physical signs of SLE exacerbation were detected. He had no family history of bleeding and was diagnosed with acquired coagulation defects.

The laboratory values were as follows: Positive antinuclear antibodies (ANA) 1:160 with homogeneous pattern and lupus anti-coagulant (LAC) screen/ LAC confirm 1.78 (n.v. 0.8-1.2; hemoglobin (Hb), 10.9 g/dl (n.v.12.2-18.1); white blood count, $6.610 / \mu \mathrm{l}$ (n.v. 4.600-10.200); platelet count, 103x 103/ul (n.v 142-424); international normalized ratio (INR) of prothrombin time (PT) 1.82 (n.v. 0.88-1.20); activated partial prothromboplastin time (aPTT), $63.7 \mathrm{~s}$ (n.v. 25.00-35.00); FII activity 28.5\% (n.v. 50-150); FVII activity $77.2 \%$ (n.v. 50-129); FVIII activity $19.5 \%$ (n.v. 50-150); and FVIII inhibitor 0.7 Bethes- da units (BU)/ml; FIX activity $14.9 \%$ (n.v. 65-150); FX activity $73.8 \%$ (n.v. 77-131); vWF-Ag 55.8\% (n.v. 61-157); C3 complement fraction $60.4 \mathrm{mg} / \mathrm{dl}$ (n.v. 79-152); sedimentation rate $19 \mathrm{~mm}$ (n.v. 1-7). Neither anti-double-stranded DNA antibodies nor anticardiolipin antibody was detected. Urinalysis failed to reveal any abnormalities. The results of blood chemistry tests are shown in Table 1.

According to anamnesis and laboratory results, acquired inhibitor to coagulation factors was diagnosed. He was treated with oral prednisolone administration $(1 \mathrm{mg} / \mathrm{kg} /$ day $)$. Three months after treatment, his laboratory date improved; hemoglobin13.9 g/dl (n.v.12.2-18.1); white blood count $12.500 / \mu \mathrm{l}$ (n.v. 4.600-10.200); platelet count 246x 103/ $\mu$ l (n.v 142-424) ; international normalized ratio (INR) of prothrombin time (PT) 1.22 (n.v. 0.88-1.20); activated partial prothromboplastin time (aPTT) $42.3 \mathrm{~s}$ (n.v. 25.00-35.00); FVIII activity $45.3 \%$ (n.v. 50-150); FIX activity $25.0 \%$ (n.v. 65-150). Furthermore oral prednisolone had continued about 6 months. At the and of treatment the laboratory studies disclosed the following values: positive ANA 1:160 with homogeneous pattern and LAC screen/ LAC confirm 1.84 (n.v. 0.8-1.2); hemoglobin $14.5 \mathrm{~g} / \mathrm{dl}$ (n.v.12.2-18.1); white blood count $14.800 / \mu$ l (n.v. 4.600-10.200); platelet count $275 \times 10^{3} / \mu l$ (n.v 142-424); international normalized ratio (INR) of prothrombin time (PT) 0.97 (n.v. 0.88-1.20); activated partial prothromboplastin time (aPTT) $41.2 \mathrm{~s}$ (n.v. 25.00-35.00); FII activity $67.2 \%$ (n.v. 50-150); FVII activity $87.7 \%$ (n.v. 50-129); FVIII activity $88.7 \%$ (n.v. 50-150); FIX activity $105.3 \%$ (n.v. 65-150); FX activity $101.9 \%$ (n.v. 77-131); vWF-Ag $105.0 \%$ (n.v. 61157). Therefore the clotting tests were become completely normal (Table 2).

\section{DISCUSSION}

A multidisciplinary approach is recommended for SLE patients. SLE may begin in any age but especially it seems in 2nd and 4th decades. ${ }^{8}$ SLE predominantly affects women with a high incidence and is uncommon in men. ${ }^{9,10}$ In some previous studies, the incidence was found as $89 \%$ females and $11 \%$ males and $92 \%$ women and $8 \%$ men. ${ }^{11,12}$ Antibodies to many clotting factors have been described in patients with SLE, including factors VIII, IX, XI, XII and XIII. ${ }^{13}$ Acquired inhibitors to other coagulation fac- 
Table 1. The results of blood chemistry tests of the patient.

\begin{tabular}{|llll|}
\hline & Results & Unit of Measurement & Normal Values \\
\hline Urea nitrogen & 39 & $\mathrm{mg} / \mathrm{dl}$ & $10-45$ \\
Creatinine & 0.9 & $\mathrm{mg} / \mathrm{dl}$ & $0.6-1.3$ \\
Sodium & 151 & $\mathrm{mmol} / \mathrm{L}$ & $136-145$ \\
Potassium & 4.1 & $\mathrm{mmol} / \mathrm{L}$ & $3.5-4.5$ \\
Chlorine & 116 & $\mathrm{mmol} / \mathrm{L}$ & $98-109$ \\
Calcium & 8.5 & $\mathrm{mg} / \mathrm{dl}$ & $8.4-10.2$ \\
Phosphorus & 3.7 & $\mathrm{mg} / \mathrm{dl}$ & $2.7-4.5$ \\
Uric acid & 6.1 & $\mathrm{mg} / \mathrm{dl}$ & $2.6-7.2$ \\
Alkaline phosphatase & 81 & $\mathrm{U} / \mathrm{L}$ & $40-150$ \\
Aspartate aminotransferase & 19 & $\mathrm{U} / \mathrm{L}$ & $10-40$ \\
Alanine aminotransferase & 13 & $\mathrm{U} / \mathrm{L}$ & $10-35$ \\
Lactate dehydrogenase & 190 & $\mathrm{U} / \mathrm{L}$ & $125-243$ \\
Triglycerde & 149 & $\mathrm{mg} / \mathrm{dl}$ & $50-180$ \\
Cholesterol & 104 & $\mathrm{mg} / \mathrm{dl}$ & $112-200$ \\
& & & \\
\hline
\end{tabular}

Table 2. Pre-treatment and post-treatment clotting tests results.

\begin{tabular}{|c|c|c|}
\hline CLOTTING TESTS & Pre-treatment & Post-treatment \\
\hline $\mathrm{ANA}^{*}$ & $1: 160$ & $1: 160$ \\
\hline LAC ${ }^{\star \star}$ screen/ & 1.78 & 1.84 \\
\hline \multicolumn{3}{|l|}{ LAC confirm } \\
\hline Platelet Count & $103 \times 10^{3} / \mu l$ & $275 \times 10^{3} / \mu l$ \\
\hline $\mathrm{INR}^{\star \star \star \star}$ & 1.82 & 0.97 \\
\hline $\mathrm{APT} T^{\star \star \star \star}$ & 63.7 & 41.2 \\
\hline Fll activity & $28.5 \%$ & $67.2 \%$ \\
\hline FVII activity & $77.2 \%$ & $87.7 \%$ \\
\hline FVIII activity & $19.5 \%$ & $88.7 \%$ \\
\hline FIX activity & $14.9 \%$ & $105.3 \%$ \\
\hline FX activity & $73.8 \%$ & $101.9 \%$ \\
\hline WWF-Ag & $55.8 \%$ & $105.0 \%$ \\
\hline \multicolumn{3}{|c|}{$\begin{array}{l}\text { *ANA: Antinuclear antibodies }{ }^{* \star L A C:} \text { Lupus an } \\
{ }^{* \star \star} \text { INR: International normalized ratio } \\
{ }^{\star * \star \star A P T T: ~ A c t i v a t e d ~ p a r t i a l ~ t h r o m b o p l a s t i n ~ t i m e ~}\end{array}$} \\
\hline
\end{tabular}

tors, including factors IX, XI, XIII, vWF protein, and the vitamin K-dependent proteins are extremely rare. ${ }^{7}$ In patients with acquired FVIII inhibitors, soft tissues and skin hemorrhages are the most frequent symptom. The inhibitory titers do not always correlate with the severity or patterns of bleeding. ${ }^{14}$ The underlying causes vary, but it should be noted that the FVIII inhibitory level is not always correlated with underlying disease activity. ${ }^{24}$ Acquired inhibitors of FVIII have rarely been reported in the presence of SLE. ${ }^{22}$ In our case, acquired hemophilia developed after a long-lasting remission of SLE. There was no evidence of any triggering event able to induce a specific antibody production or unspecific B cell stimulation such as infections as vaccines.

FVIII auto-antibody inhibitors, though rare, may present significant and often life-threatening haemorrhage. The principles of therapy are similar to those which apply to the management of FVIII auto-antibodies. Treatment of patients with acquired FVIII inhibitors varies depending upon the underlying medical condition, the titre of the inhibitory, and the clinical presentation. When reviewing literature, there was no consensus on the treatment of SLE associated with FVIII inhibitors. The aims of treat- 
Table 3. Review of reported cases with acquired hemophilia in patients with systemic lupus erythematosus (SLE)

\begin{tabular}{|c|c|c|c|c|c|c|c|}
\hline $\begin{array}{l}\text { Case } \\
\text { no }\end{array}$ & $\begin{array}{l}\text { Author } \\
\text { (Reference no) }\end{array}$ & $\begin{array}{l}\text { Age/ } \\
\text { sex }\end{array}$ & $\begin{array}{l}\text { APTT" }^{*}(\mathbf{s}) \\
{ }^{*}(\mathrm{~s})\end{array}$ & $\begin{array}{l}\text { FVIII level } \\
\text { (\%) }\end{array}$ & $\begin{array}{l}\text { FVIII inhibitor } \\
\left(\mathrm{BU}^{\star \star} / \mathrm{ml}\right)\end{array}$ & $\begin{array}{l}\text { SLE } \\
\text { activity }\end{array}$ & $\begin{array}{l}\text { Treatment } \\
\text { (outcome) }\end{array}$ \\
\hline 1 & Pirner et al. ${ }^{19}$ & $27 / F$ & 77 & $<3$ & 1.4 & Active & Com. Theraphy (improved) \\
\hline 2 & Schwartz et al. ${ }^{20}$ & $40 / F$ & NA & $<1$ & 7.2 & $N A^{\star \star \star}$ & Com. Theraphy (improved) \\
\hline 3 & Schulman et al..$^{21}$ & $27 / F$ & 42 & $<1$ & 16 & Active & Com. Theraphy (improved) \\
\hline 4 & Lafferty et al. ${ }^{22}$ & $45 / F$ & 66 & $<1$ & 2.8 & NA & Com. theraphy (improved) \\
\hline 5 & Trotta et al. ${ }^{23}$ & $19 / F$ & 54.6 & 3 & 2.8 & Active & Com. theraphy (improved) \\
\hline \multirow[t]{2}{*}{6} & Ishikawa et al. ${ }^{24}$ & $24 / F$ & 116 & 2.8 & 46.5 & Inactive & Com. theraphy (improved) \\
\hline & Nishino et al. ${ }^{25}$ & & & & & & \\
\hline 7 & Kornfeld et al. ${ }^{26}$ & $30 / F$ & 79 & 1 & 7.7 & Active & Com. theraphy (improved) \\
\hline 8 & Onishi et al. ${ }^{27}$ & $54 / F$ & 77.3 & $<2$ & 38.7 & Inactive & Com. theraphy (improved) \\
\hline 9 & Akahoshi et al. ${ }^{28}$ & $39 / F$ & 90.4 & $<1$ & 1.3 & Active & Com. theraphy (improved) \\
\hline 10 & Present case & $22 / \mathrm{M}$ & 63.7 & 19.5 & 0.7 & Inactive & Mono theraphy (improved) \\
\hline
\end{tabular}

*APTT: Activated partial thromboplastin time, ${ }^{\star \star} \mathrm{BU}$ : Bethesda unit, ${ }^{* \star \star N A: ~ n o t ~ a v a i l a b l e, ~ M o n o ~ t h e r a p y: ~ P r e d n i s o l o n e, ~}$

Combination therapy: Factor VIII concentrate, Azathioprine, Cyclophosphamide, Ccyclosporine, Intravenous immunoglobulin, Activated prothrombin complex concentrate, Plasmapheresis, Dexamethasone, Methotrexate, Prothrombin complex concentrate.

ment are to eliminate the inhibitory by immunosuppression and to treat the bleeding, which is the most common cause of death in patients with acquired haemophilia. ${ }^{6}$ Elimination of the inhibitory is usually achieved through long-term immunosuppression of antibody formation with corticosteroids, cytotoxic agents, such as cyclophosphamide and cyclosporine, or combination therapy, as well as intravenous immunoglobulin therapy and/or plasmapheresis or immunoadsorption. ${ }^{15,16}$ To reduce or eliminate FVIII inhibitory, several therapeutic interventions have been tried. Prednisolone and cyclophosphamide are generally used to treat acquired hemophilia. The inhibitory is abolished in up to $70 \%$ of patients using prednisolone and cyclophosphamide. ${ }^{6}$ Glucocorticoids are recommended as an initial treatment of non-hemophilic patients with FVIII inhibitory ${ }^{17}$ and cyclophosphamide is effective as second-line therapy for many of those who are steroid resistant..$^{15,18,22}$

Among previous investigations of acquired hemophilia along with SLE, ten cases (including our case) are available, and the features of these reported cases are summarized in Table 3..$^{19-28}$ As reported in other similar cases, a careful follow-up of the clotting tests is important to evaluate the response to therapy and the risk of new hemorrhagic manifestations. In our case normalization of the clotting tests were achieved after 6 month since the start of treatment which was enough monotheraphy with prednisolone, although other nine similar cases were needed combination therapy for controlling the disease.

When we reviewing literature about developing acquired inhibitors to coagulation factors with SLE patients we have found some cases that developing acquired inhibitors to FIX (5), FXI ${ }^{29}$ and FXIII ${ }^{30}$ with or without FVIII. However, in our case acquired inhibitors developed not only against FVIII but also to FII, FIX, FX and vWF-Ag.

According to our reviewing literature, so far, our case is the only male patient with SLE who developed acquired coagulation inhibitors against to FII, FVIII, FIX, FX and vWF-Ag

\section{REFERENCES}

1. Rovensky J, Tuchynova A. Systemic lupus erythematosus in the elderly. Autoimmun Rev 7: 235-239, 2008.

2. Boumpas DT, Austin HA 3rd, Fessler BJ, et al. Systemic lupus erythematosus: emerging concepts. Part 1: Renal, neuropsychiatric, cardiovascular, pulmonary and hematolojic disease. Ann Intern Med 122: 940950, 1995. 
3. Gladman DD, Urowitz MB. Connective tissue disorders. Systemic lupus erythematosus. Clinical features. In: Klippel JH, Dieppe PA, editors. Rheumatology. Mosby, London, 1994: 6.2.1.-20.

4. Maddison PJ. Systemic lupus erythematosus in the elderly. J Rheumatol 14(suppl 13):182-7, 1987.

5. Porru G, Mura V, Piga M, et al. Hemarthrosis as acute presentation of acquired hemophilia in a patient with systemic lupus erythematosus: successful treatment and long-lasting remission. Clin Rheumatol 27: 15811584, 2008.

6. Hay CR. Acquired haemophilia. Baillieres Clin Haematol 11: 287-303, 1998.

7. Cohen AJ, Kessler CM. Acquired inhibitors. Baillieres Clin Haematol 9: 331-54, 1996.

8. Goldman L, Bennet JC (eds). Cecil Textbook of Medicine, In: Systemic Lupus Erythematosus. Edited by Schur PH. W.B. Saunders company, 21st edition, 2000: 1509-17.

9. Boddaert J, Huong du LT, Amoura Z, et al. Late-Onset Systemic Lupus Erythematosus. Medicine 83: 348359, 2004.

10. Chang CC, Shih TY, Chu SJ, et al. Lupus in Chinese male: a retrospective study of 61 patients. Zhonghua Yi Xue Za Zhi (Taipei) 55: 143-50, 1995.

11. Font J, Pallarés L, Cervera R, et al. Systemic lupus erythematosus: a clinical and immunological study of 300 patients. Med Clin (Barc) 24;100: 601-5, 1993.

12. Houman MH, Smiti-Khanfir M, Ben Ghorbell I, Miled M. Systemic lupus erythematosus in Tunisia: demographic and clinical analysis of 100 patieents. Lupus 13: 204-11, 2004.

13. Goldman Lee, Ausiello Dennis. Cecil textbook of Medicine, 22nd Edition. International Edition Printed in the U.S.A. 2004: 1660-1670.

14. Yee TT, Taher A, Pasi KJ, Lee CA. A survey of patients with acquired haemophilia in a haemophilia centre over a 28- year period. Clin Lab Haematol 22: 275278, 2000.

15. Green D, Rademaker AW, Briet E. A prospective, randomized trial of prednisone and cyclophosphamide in the treatment of patients with factor VIII autoantibodies. Thromb Haemost 70: 753-757, 1993.

16. Zeitler H, Ulrich-Merzenich G, Hess L, et al. Treatment of acquired hemophilia by the Bonn-Malmo Protocol: documentation of an in vivo immunomodulating concept. Blood 105: 2287-2293, 2005.

17. Boggio LN, Gren D. Acquired hemophilia. Rev Clin Exp Hematol 5: 389-404, 2001.

18. Morrison AE, Ludlam CA. Acquired haemophilia and its management. Br J Haematol 89: 231-236, 1995.

19. Pirner K, Rosler W, Kalden JR, Manger B. Long-term remission after i.v. immunoglobulin therapy in acquired antihemophilic factor hemophilia with systemic lupus erythematosus. Z Rheumatol 49: 378-81, 1990.

20. Schwartz RS, Gabriel DA, Aledort LM, et al. Prospective study of treatment of acquired (autoimmune) fac- tor VIII inhibitors with high-dose intravenous gammaglobulin. Blood 86: 797-804, 1995.

21. Schulman S, Langevitz P, Livneh A, et al. Cyclosporine therapy for acquired factor VIII inhibitory in a patient with systemic lupus erythematosus. Thromb Haemost 76: 344-346, 1996.

22. Lafferty TE, Smith JB, Schuster SJ, DeHoratius RJ. Treatment of acquired factor VIII inhibitory using intravenous immunoglobulin in two patients with systemic lupus erythematosus. Arthritis Rheum 40: 775-778, 1997.

23. Trotta F, Bajocchi G, La Corte R, et al. Long lasting remission and successful treatment of acquired factor VIII inhibitors using cyclophosphamide in a patient with systemic lupus erythematosus. Rheumatology 38: 1007-1009, 1999.

24. Ishikawa T, Tsukamoto N, Suto M, et al. Acquired hemophilia $A$ in a patient with systemic lupus erythematosus. Intern Med 40: 541-543, 2001.

25. Nishino $Y$, Ueki K, Suto M, et al. Successful treatment of patients with rheumatic disorders and acquired factor VIII inhibitors with cyclophosphamide and prednisolone combination therapy: two case reports. J Int Med Res 29: 432-436, 2001.

26. Kornfeld S, Veyssier-Belot C, Vinceneux A, et al. Acquired haemophilia in a patient with systemic lupus erythematosus. Ann Dermatol Venereol 129: 316-319, 2002.

27. Onishi S, Hojo N, Sakai I, et al. Rupture of the gallbladder in a patient with acquired factor VIII inhibitors and systemic lupus erythematosus. Intern Med 43: 1073-1077, 2004.

28. Akahoshi M, Aizawa K, Nagano S, et al. Acquired hemophilia in a patient with systemic lupus erythematosus: A case report and literature review. Mod Rheumatol 18: 511-515, 2008.

29. Bortoli R, Monticielo OA, Chakr RM, et al. Acquired Factor XI Inhibitor in Systemic Lupus ErythematosusCase Report and Literature Review. Semin Arthritis Rheum. 2008 May 31. http://www.unboundmedicine.com/medline/ebm/record/18519152 (Access date: 20/11/2009).

30. Ahmad F, Solymoss S, Poon MC, et al. Characterization of an acquired IgG inhibitor of coagulation factor $\mathrm{XIII}$ in a patient with systemic lupus erythematosus. $\mathrm{Br}$ J Haematol 93: 700-703, 1996.

\section{Correspondence}

Dr. Özgür ERDEM

Dicle Üniversitesi Tıp Fakültesi

Aile Hekimliği Anabilim Dalı

DIYARBAKIR / TURKEY

Tel: (+90.412) $2488001 / 5662$

E-mail: dr.oerdem@hotmail.com 